\title{
A new species of Micropterix Hübner, 1825 from Lebanon (Lepidoptera: Micropterigidae)
}

\author{
Hans Christof Zeller ${ }^{1}$, JaAkKo Kullberg ${ }^{2}$, Michael Alexander KurZ ${ }^{3}$ \\ 1 Forsthubfeld 14, A-5303 Thalgau, Austria; christof.zeller@gmx.net \\ 2 Harmaahaikarankuja 3 I 9, FI-00940 Helsinki, Finland; jaakko.kullberg@gmail.com \\ 3 Josef-Waach-Strasse, 13/1,A-5020 Salzburg, Austria; michael.kurz@gmx.at \\ http://zoobank.org/98F3BD47-CDFD-4F4E-AEE7-6430427AC7CF
}

Received 21 April 2016; accepted 1 July 2016; published: 1 August 2016

Subject Editor: Erik van Nieukerken.

\begin{abstract}
Micropterix jabalmoussae Zeller, Kullberg \& Kurz, sp. n. is described from the mountain Jabal Moussa Biosphere Reserve (Lebanon) and compared with all other known species of Micropterix from this region and similar species of the Western Palaearctic. M. jabalmoussae is the fifth species of the genus Micropterix Hübner, 1825 known from the Levant.
\end{abstract}

\section{Introduction}

The genus Micropterix is distributed through the Palaearctic from North Africa and Europe to Japan in the east (Gibbs 1987; Zeller et al. 2013; Gibbs and Lees 2014) and even down to the foothills of the Himalayas (Lees et al. 2010). This study of a new species follows the recently published review of Micropterix of Cyprus and the Middle East (Zeller-Lukashort et al. 2009).

This description is based on two specimens collected by Jaakko Kullberg and Tommi Lievonen in Lebanon from the naturally rich Biosphere Reserve of Jabal Moussa (The Mountain of Moyses) located about $50 \mathrm{~km}$ north-east of the capital city Beirut in the Keserwan-Jbeil area, on the western side of the Mount Lebanon high plateau. The topography of the area is impressive. There is a Mediterranean vegetation zone starting at an elevation of $300 \mathrm{~m}$ grading up to arid mountain habitats surpassing $1700 \mathrm{~m}$ altitude on the high plateau (Association for the Protection of Jabal Moussa (APJM) 2016). Locally, Jabal Moussa carries a special importance, as it was designated in 2009 as the third biosphere reserve in Lebanon as part of the UNESCO Network of Biosphere Reserves under the Man \& Biosphere (MAB) program. The reserve is surrounded by Nahr Ibrahim and Nahr Ed-Dahab rivers and the mountain is rich in local fauna and flora. For more information see http:// www.jabalmoussa.org. Especially at higher altitudes from $700 \mathrm{~m}$ and upwards the Lepidoptera fauna is mostly of Irano-Turanian origin and partly east Mediterranean, but in fact several familiar widespread species common to the Central European fauna are present in the mountains. Many of these are close to the southernmost edge of their distribution. 


\section{Methods}

The morphology of the new species is compared with all other known species from this region and also with similar species of the Western Palaearctic (Kurz and Kurz 2016) ${ }^{1}$. We consequently build on the important identification treatments by Heath (1987), Kozlov (1989, 1990a, b) and Zeller-Lukashort et al. (2007).

The genitalia preparation follows standard techniques used for the family Micropterigidae. Due to the problems and difficulties in preparing female genitalia of specimens in the genus Micropterix, no attempt has been made to prepare the genitalia of the single available female of the new species (Zeller-Lukashort et al. 2007).

The photograph of the holotype was taken with a NIKON D200 digital camera, a NIKON Micro-Nikkor 105mm 1:2.8 lens and three LED lamps for illuminating. The photograph of the male genitalia of the holotype was taken with an OLYMPUS FHT trinocular microscope and NIKON D800 digital camera, manipulated using the focus stacking software HELICON FOCUS 6.4.1 to extend depth of field. All photos were developed using ADOBE PHOTOSHOP CS2.

For more information about collection sites, preparation techniques and a data archive of $\mathrm{Mi}$ cropterix spp. see Zeller-Lukashort et al. (2007).

The two studied specimens are deposited in the Finnish Museum of Natural History, University of Helsinki, Finland (MZH).

\section{Results}

\section{Checklist of Micropterix of the Levant}

The following species occur within the Levant (Wikipedia 2016) presented here in alphabetical order (Zeller-Lukashort et al. 2009; Kurz and Kurz 2016).

Micropterix berytella de Joannis, 1886

Micropterix cypriensis Heath, 1985

Micropterix elegans Stainton, 1867

Micropterix islamella Amsel, 1935

Micropterix jabalmoussae sp. n.

\section{Taxonomic part}

\section{Micropterix jabalmoussae Zeller, Kullberg \& Kurz, sp. n.}

http://zoobank.org/AEE90EBE-86C8-4243-816A-D2F6291DA492

Material. Holotype $\delta^{`}$ : http://id.luomus.fi/GK.6673, Lebanon, Kesrouan 950 m, 3403.96’N 3545.07’E, Jebel Musa, Mar Geryes, 25.v.2012, J. Kullberg \& T. Lievonen leg., label with identification numbers CZ-Z27207 and AP: MK-

To access informations about these species login as "guest" at http://www.nkis.info, go first to "DATA ANALYSIS" (top menu) and choose "taxonomical descriptions (individual query)" (left side menu) and then input the taxonomic name of the requested species in the input field that will now display (main window). 


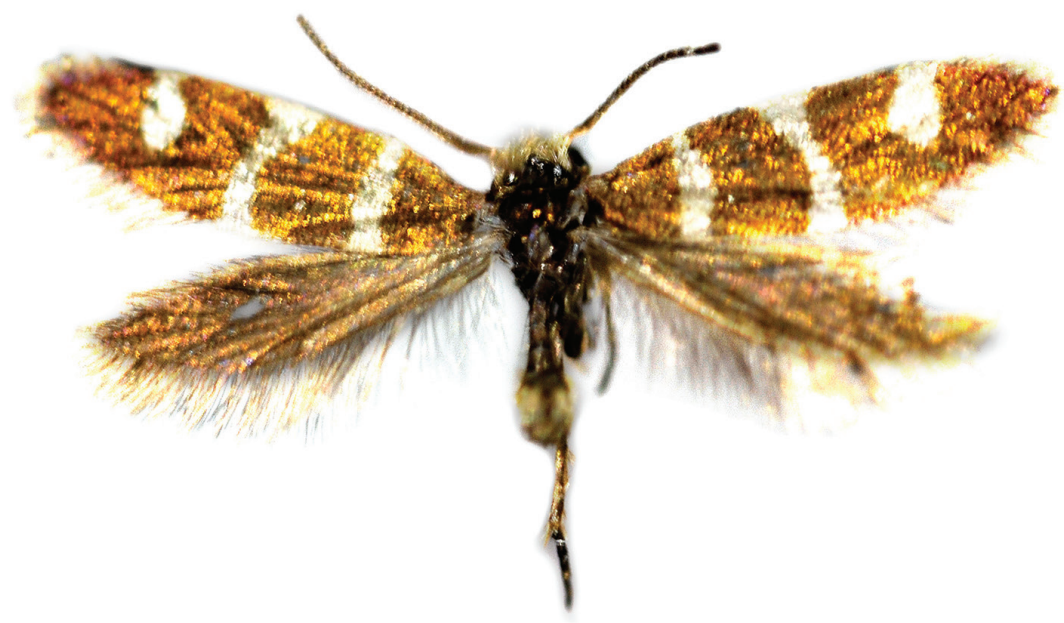

Figure 1. Male holotype of M. jabalmoussae sp. n.

1062 and red label "HOLOTYPE of Micropterix jabalmoussae Zeller, Kullberg \& Kurz". - Paratype: 1 \&, same data as holotype but http://id.luomus.fi/GK.6675, label with identification numbers CZ-Z27208 and red label "PARATYPE of Micropterix jabalmoussae Zeller, Kullberg \& Kurz.

Description. Adult (Fig. 1). Forewing length $3.5 \mathrm{~mm}\left({ }^{\lambda}\right), 3.6 \mathrm{~mm}$ () $)$. Head black-brown; vestiture of hair-like scales on head light yellow; antennae dark brown, 3/4 (đ)), respectively, $1 / 2$ () forewing length; thorax and tegulae violet with golden gloss; forewings bronze golden, with purple tinge at apex, with silvery white markings: a narrow fascia across whole wing width at $1 / 4$; a narrow, outwardly bent fascia across whole wing width at nearly $1 / 2$, somewhat broadened at costa; at $3 / 4$ an oval or rectangular spot reaching from costa to middle of the forewing; fringe bronzy golden; hindwings bronzy golden, apically tinged purplish; fringe bronzy golden; legs and abdomen brown, golden shining.

Male genitalia (Fig. 2). Uncus very short and stout, beneath uncus a sclerotized twin structure of curved and slender shape, bearing hair-like setae at tip; accessory claspers nearly square, distally with rounded margin, bearing three groups of setae: about ten long setae with hooked ends at distal margin, a group of about eight $\mathrm{T}$-shaped setae on inner surface and more dorsally and two clearly separated setae also on inner surface but more ventrally (Fig. 3); valvae moderately long, base thickened, medially distinctly constricted, distal parts spoon-like; distal parts at inner surface with one to two rows of short, straight, stout and thickened setae at ventral margin; phallus typical for genus, without cornuti.

The twin structures overlying the ventral margin of the accessory claspers randomly are part of the phallus and do not belong to the accessory claspers. 


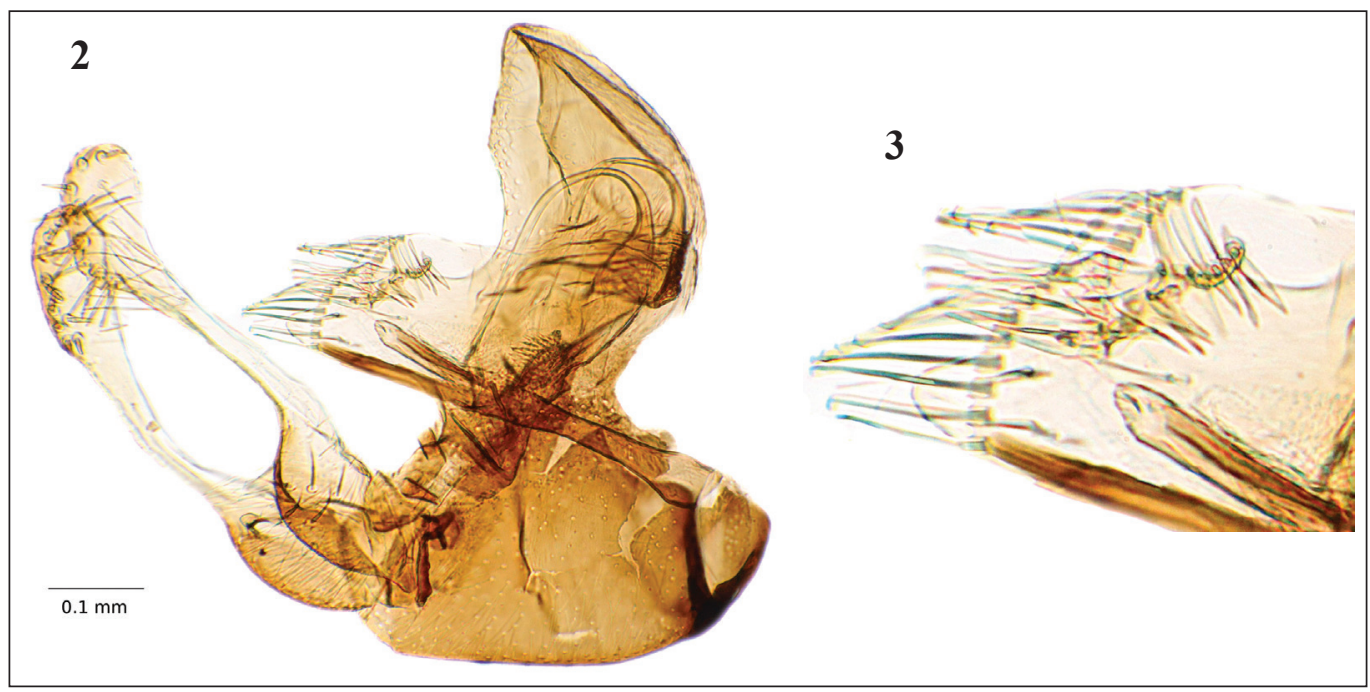

Figures 2-3. 2. Male genitalia of M. jabalmoussae sp. n. (holotype). 3. Accessory claspers of male genitalia in higher magnification.

Diagnosis. $M$. berytella and $M$. elegans occur in the same region and show similar wing markings (Zeller-Lukashort et al. 2009). The new species is externally somewhat similar to M. cypriensis (Cyprus), M. corcyrella Walsingham, 1919 (southern Balkans), M. aruncella (Scopoli, 1763) (Europe), M. erctella Walsingham, 1919 (Sicily), M. uxoria Walsingham, 1919 (Sicily), M. renatae Kurz et al., 1997 (Italy) and M. italica Heath, 1981 (Italy). From all these species the new species is clearly separated by its male genitalia, e.g. by the distinct shape of uncus, accessory claspers and valvae (Zeller-Lukashort et al. 2007, 2009; Kurz and Kurz 2016). In the male genitalia the new species somewhat resembles M. wockei Staudinger, 1970 from Greece but can easily be distinguished by its different valvae and shorter uncus (Kurz and Kurz 2016). M. islamella was found together with the new species but can easily be distinguished by its different wing pattern (Zeller-Lukashort et al. 2009).

Distribution. The new species is so far known from the mountain Jebel Musa (Kesrouan, Lebanon) from an elevation of about $950 \mathrm{~m}$.

Life history. The early stages are unknown. The new species was found in a dry slope meadow within a semi-open forest with Malus sp., Crataegus sp., Rosa sp., Sorbus sp., Prunus sp. and Quercus sp. (Figs 4, 5). M. islamella was also found at the same locality.

Etymology. The name of the new species is derived from the mountain Jebel Musa, also transcribed as Jabal Moussa or Gebel Musa, which literally means "The Mountain of Moyses".

Remark. Based on morphological characters the new species is considered to belong to a species-complex together with M. aglaella (Duponchel, 1838), M. wockei, M. aureatella (Scopoli, 1763), M. herminiella Corley, 2007 and M. sikhotealinensis Ponomarenko \& Beljaev, 2000 (Kurz et al. 2016).

During the dissection of the male genitalia of the holotype, the whole body (abdomen, thorax, mesothorax, legs and wings) was unfortunately severed from the head. The broken part is stored in a micro vial attached on the pin. Figure 1 was taken before dissecting. 

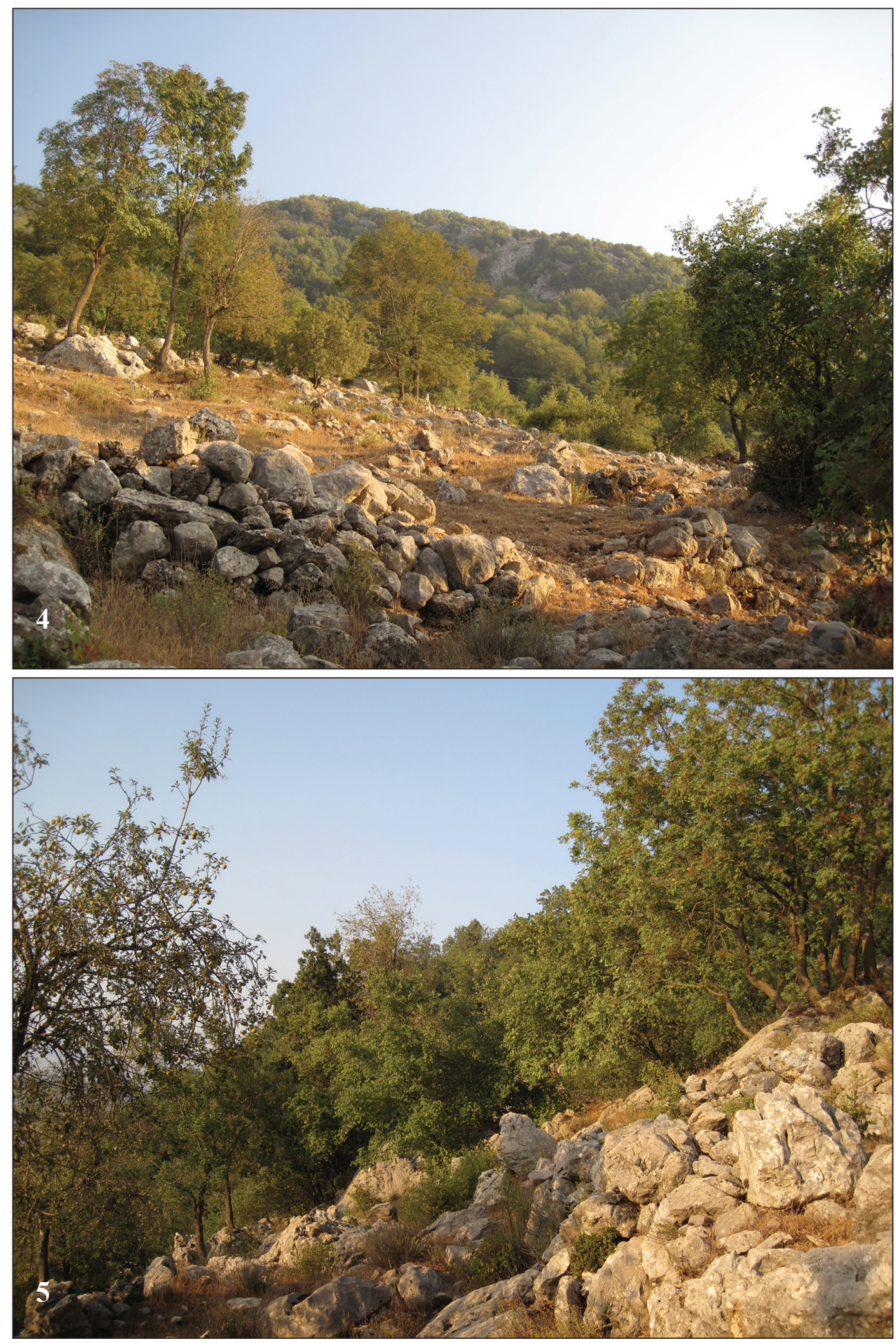

Figures 4-5. Type locality of M. jabalmoussae sp. n.. 


\section{Acknowledgements}

We are grateful to Dr. David Lees (London) and Martin Corley (Faringdon, Oxford), who kindly improved our English and gave us useful hints and to Dr. Erik van Nieukerken (Leiden) for his kind support during the review process. The first author is particularly grateful to the late Mrs. Christine Maierhofer, former principal of the elementary school of St. Peter am Wallersberg (Carinthia, Austria), for supporting his research. The second author is very grateful for the Association for Protection of Jabal Moussa Biosphere, its most helpful staff and especially Pierre Doumet for the excellent opportunity for accommodation and research possibilities in the reserve. The project was funded and supported by Mr. Heikki Seppälä, KuvaSeppälä-yhtiöt Oy and the Helsingin hyönteistieteellinen yhdistys.

\section{References}

Association for the Protection of Jabal Moussa (APJM) (2016) Association for the Protection of Jabal Moussa. http://www.jabalmoussa.org/ [Last accessed: April 14, 2016]

Gibbs GW (1983) Evolution of Micropterigidae (Lepidoptera) in the SW Pacific. GeoJournal 7(6): 505-510. doi: $10.1007 / \mathrm{bf} 00218523$

Gibbs GW, Lees DC (2014) New Caledonia as an evolutionary cradle: a re-appraisal of the jaw-moth genus Sabatinca (Lepidoptera: Micropterigidae) and its significance for assessing the antiquity of the island's fauna. In: Guilbert É, Robillard T, Jourdan H, Grandcolas P (Eds) Zoologia Neocaledonica 8. Biodiversity studies in New Caledonia. Muséum national d'Histoire naturelle, Paris, 239-266. [Mémoires du Muséum national d'Histoire naturelle; 206]

Heath J (1987) A check list of the genus Micropterix Hübner [1825] (Lepidoptera: Zeugloptera, Micropterigidae). Entomologist's Gazette 38: 205-207.

Karsholt O (2013) Fauna Europaea: Micropterigidae. Fauna Europaea version 2.6.2. http://www.faunaeur.org [Last accessed April 14, 2016]

Kozlov MV (1989) Short review and key for determination of Micropterix Hbn. (Lepidoptera, Micropterigidae) species of Palaearctic. 2. Key for determination (pt. 1). Vestnik zoologii 6: 26-31. [In Russian, English summary]

Kozlov MV (1990a) Short review and key for determination of Micropterix Hbn. (Lepidoptera, Micropterigidae) species of Palaearctic. 3. Key for determination (pt. 2). Vestnik zoologii 2: 21-26. [In Russian, English summary]

Kozlov MV (1990b) Short review and key for determination of Micropterix Hbn. (Lepidoptera, Micropterigidae) species of Palaearctic. 4. Results of investigation of the type species. Vestnik zoologii 3: 28-33. [In Russian, English summary]

Kristensen NP (1999) The non-Glossatan Moths. Ch. 4. In: Kristensen NP (Ed.) Lepidoptera, Moths and Butterflies. Volume 1: Evolution, Systematics, and Biogeography. Handbuch der Zoologie. Eine Naturgeschichte der Stämme des Tierreiches / Handbook of Zoology. A Natural History of the phyla of the Animal Kingdom. Band / Volume IV Arthropoda: Insecta Teilband / Part 35. Walter de Gruyter, Berlin, New York, 41-49.

Kurz MA, Kurz ME, Zeller-Lukashort HC (2004) A new Micropterix species from southern France (Micropterigidae). Nota Lepidopterologica 26(3/4): 111-114.

Kurz MA, Kurz ME (2016) Naturkundliches Informationssystem. http://www.nkis.info [Last accessed: March 1, 2016]

Kurz MA, Kurz ME, Zeller HC (2016) Morphological characters as indicators for a hypothetical arrangement of species in the genus Micropterix Hübner. Mitteilungen der Naturkundlichen Gesellschaft. http://www. nkis.info/MittnatGes 
Lees DC, Rougerie R, Zeller-Lukashort C, Kristensen NP (2010) DNA mini-barcodes in taxonomic assign-ment: a morphologically unique new homoneurous moth clade from the Indian Himalayas described in Micropterix (Lepidoptera, Micropterigidae). Zoologica Scripta 39(6): 642-661. doi: 10.1111/j.14636409.2010.00447.x

Wikipedia (2016) The Free Encyclopedia. https://en.wikipedia.org/wiki/Levant [Last accessed: March 1, 2016]

Zeller-Lukashort HC, Kurz ME, Lees DC, Kurz MA (2007) A review of Micropterix Hübner, 1825 from northern and central Europe (Micropterigidae). Nota Lepidopterologica 30(2): 235-298.

Zeller-Lukashort HC, Kurz MA, Lees DC, Schwartz-Tzachor R (2009) Micropterix of Cyprus and the Middle East (Micropterigidae). Nota Lepidopterologica 32(2): 129-138.

Zeller-Lukashort HC, Werno A, Kurz MA (2013) A new species of Micropterix Hübner, [1825] from southern Spain (Lepidoptera: Micropterigidae). SHILAP Revista de Lepidopterologia 41(164): 489-494. 